\title{
Contribution to the knowledge of the subgenus Scymnus (Parapullus) Yang, 1978 (Coleoptera, Coccinellidae), with description of eight new species
}

\author{
Xiaosheng Chen ${ }^{1}$, Shunxiang Ren ${ }^{1}$, Xingmin Wang ${ }^{1}$ \\ 1 Engineering Research Center of Biological Control, Ministry of Education; College of Agriculture, South China Agricultural University, Guangzhou \\ 510642, China
}

http://zoobank.org/075E2200-7B72-481B-8D15-87708FD1A8BE

Corresponding author: Shunxiang Ren (shxren@scau.edu.cn); Xingmin Wang (wangxmcn@scau.edu.cn)

Received 12 May 2015

Accepted 31 July 2015

Published 11 August 2015

Academic editor:

Harald Letsch

\section{Key Words}

Coccinellidae

Scymnus (Parapullus)

taxonomy

new species

distribution

catalogue

China

\begin{abstract}
Eight new species of the subgenus Scymnus (Parapullus) Yang, 1978 from China are described and illustrated: $S$. (P.) hastatus sp. n., $S$. (P.) baxianshanensis sp. n., S. (P.) laojielingensis sp. n., $S$. (P.) annuliformis sp. n., $S$. (P.) papillatus sp. n., $S .(P$. dichotomus sp. n., $S$. (P.) shenmuensis sp. n. and $S$. (P.) yanzigouensis sp. n. Diagnoses and distributions are provided for each species. An updated key to the Chinese species of the subgenus Parapullus is given. A catalogue to all known species of this subgenus is also presented.
\end{abstract}

\section{Introduction}

The subgenus Scymnus (Parapullus) was created by Yang (1978), with type species Scymnus (Parapullus) secula Yang, 1978 described from Taiwan. The distinguished characters includes: abdominal postcoxal lines distinctly incomplete laterally, antennae composed of ten antennomeres, parameres of the tegmen usually with two groups of long setae inserted in different directions.

Parapullus is a small subgenus of Scymnus, currently comprising of 12 described species worldwide and mainly distributed in the Old World (Yang 1978, Pang and Yu 1993, Yu et al. 2000, Chen et al. 2012). In China, eight species have been documented prior to the present work (Chen et al. 2012). In present study examination of ladybird specimens newly collected from various parts of China was done together with coccinellid collection of South
China Agricultural University revealing eight new species belonging to subgenus Parapullus and reported herein.

In this paper, eight new species are described and illustrated in detail, and a key to the Chinese species of the subgenus Parapullus is updated. Maps of the distribution of the species occurring in China are given. A catalogue to the worldwide species of this subgenus is also presented.

\section{Material and methods}

Measurements were made using a micrometer attached to a dissecting microscope as follows: total length (TL), from apical margin of clypeus to apex of elytra; total width (TW), across both elytra at widest part; total height $(\mathrm{TH})$, at highest part of elytra; elytral length (EL), along 
suture from base to apex including scutellum; elytral width (EW), equal to TW; pronotal length (PL), from the middle of anterior margin to the base of pronotum; pronotal width (PW), at widest part; head width (HW), at widest part including eyes.

External morphology was observed with a dissecting stereoscope (SteREO Discovery V20). Male and female genitalia were dissected, cleared in $10 \%$ solution of $\mathrm{NaOH}$ by boiling for several minutes, and examined on slides with an Olympus BX51 compound microscope. After examination, the genitalia were transferred to a small card covered with neutral balsam and pinned beneath the specimen. Photographs of the whole beetles and their genitalia were executed on digital cameras (CoolsnapProcf \& CRI Micro*Color and AxioCam HRc) and composite images generated with IMAGE-PRO PLUS 5.1 and AXIO VISION REL. 4.8 softwares. The final plates were prepared using ADOBE PHOTOSHOP CS 8.0.

Morphological terminology use in this paper follows Ślipiński (2007) and Ślipiński and Tomaszewska (2010). Type specimens designated in the present paper are deposited in the Department of Entomology, South China Agricultural University, Guangzhou, China (SCAU).

\section{Taxonomy}

\section{Scymnus (Parapullus) hastatus sp. $\mathbf{n}$.}

http://zoobank.org/E974785F-794F-4A8F-B996-22ED5BC0BF27

Figs 1,9

Diagnosis. This species is easily confused with several species having unicolourous reddish brown body in this subgenus, but can be recognized by the stout penis guide with a hook-like appendage at apex in lateral view (Fig. 1h).

Description. TL: $2.31-2.43 \mathrm{~mm}$, TW: $1.53-1.67 \mathrm{~mm}$, TH: 0.98-1.04 mm, TL/TW: 1.46-1.51, PL/PW: 0.560.57, EL/EW: 1.13-1.16, HW/PW: 0.59-0.62, PW/EW: $0.73-0.74$.

Body elongate oval, moderately convex, entirely reddish brown, dorsum covered with white pubescence (Fig. 1a-c).

Head with fine frontal punctures, as large as eye facets, 1.0-2.0 diameters apart. Eyes densely faceted, interocular distance 0.51 times head width. Pronotal punctures as large as those on frons, 2.0-3.0 diameters apart. Surface of elytra with punctures larger than those on pronotum, separated by 2.5-3.0 diameters. Prosternal process trapezoidal, 2 times as long as its width at base; with lateral carinae distinct, extending to anterior margin of prosternum, distinctly convergent anteriorly. Abdominal postcoxal lines weakly recurved and distinctly incomplete laterally (Fig. 1d), reaching 6/7 length of abdominal ventrite 1 , area enclosed by lines coarsely punctate, broadly smooth along line. Abdominal ventrite 5 in male with apex truncate.

Male genitalia: penis stout, unevenly sinuated (Fig. 1e). Penis capsule highly sclerotized with small inner arm and large outer arm (Fig. 1e). Apex of penis strongly curved with distinctly membranous appendage (Fig. 1f). Tegmen extremely stout (Fig. 1g-h) with penis guide narrowest at base, gradually expanding to a spade-like apex bearing with a digitations in ventral view (Fig. 1g); in lateral view, penis guide strongly raised at middle with a hooklike appendage at apex (Fig. 1h). Parameres slender with rounded apex, slightly longer than penis guide, densely covered with two groups of long setae at apices (Fig. 1h).

Female unknown.

Type materials. Holotype: male, No. SCAU (E) 11346, China: Gansu: Dongshan, Xinglongshan National Nature Reserve, Yuzhong County, Lanzhou City, $35^{\circ} 47.83^{\prime} \mathrm{N}, 1^{\circ} 4^{\circ} 3.93^{\prime} \mathrm{E}$, ca $2300 \mathrm{~m}$, 3. VIII. 2007, Liang JB leg. Paratypes (3): $3 \hat{\jmath}$ with same data as holotype.

Distribution. China (Gansu).

Etymology. The species name is derived from the Latin adjective hastatus referring to its penis guide with halberd-like apex in ventral view.

\section{Scymnus (Parapullus) baxianshanensis sp. $\mathbf{n}$.}

http://zoobank.org/33254854-37B7-4933-8555-241DB7137AAA Figs 2, 9

Diagnosis. This species is most similar to Scymnus (Parapullus) alishanensis Pang \& Yu, 1993 in general appearance and male genitalia, but can be distinguished from it by having parameres as long as half length of penis guide (Fig. 2h) and penis guide constricted at middle part in ventral view (Fig. $2 \mathrm{~g}$ ). In $S$. (P.) alishanensis, its parameres are longer than half length of penis guide and penis guide constricted near middle part in ventral view.

Description. TL: $2.20-2.48 \mathrm{~mm}$, TW: $1.60-1.71 \mathrm{~mm}$, TH: $1.06-1.18 \mathrm{~mm}$, TL/TW: 1.38-1.45, PL/PW: 0.540.55, EL/EW: 1.06-1.09, HW/PW: 0.59-0.60, PW/EW: $0.70-0.75$.

Body elongate oval, moderately convex, entirely reddish brown, dorsum covered with white pubescence (Fig. 2a-c).

Head with fine frontal punctures, slightly smaller than eye facets, 0.5-1.0 diameter apart. Eyes densely faceted, interocular distance 0.49 times head width. Pronotal punctures larger than those on frons, 1.0-2.0 diameters apart. Surface of elytra with punctures much larger than those on pronotum, separated by 1.0-2.0 diameters. Prosternal process trapezoidal, 2 times as long as its width at base; with lateral carinae distinct, extending to anterior margin of prosternum, slightly convergent anteriorly. Abdominal postcoxal lines weakly recurved and distinctly incomplete laterally (Fig. 2d), reaching 6/7 length of abdominal ventrite 1 , area enclosed by lines finely punctate, narrowly smooth along line. Abdominal ventrite 5 in both sexes with apex truncate.

Male genitalia: penis stout (Fig. 2e). Penis capsule deeply emarginated medially with small inner arm and large outer arm. Apex of penis slender, forming a hook- 


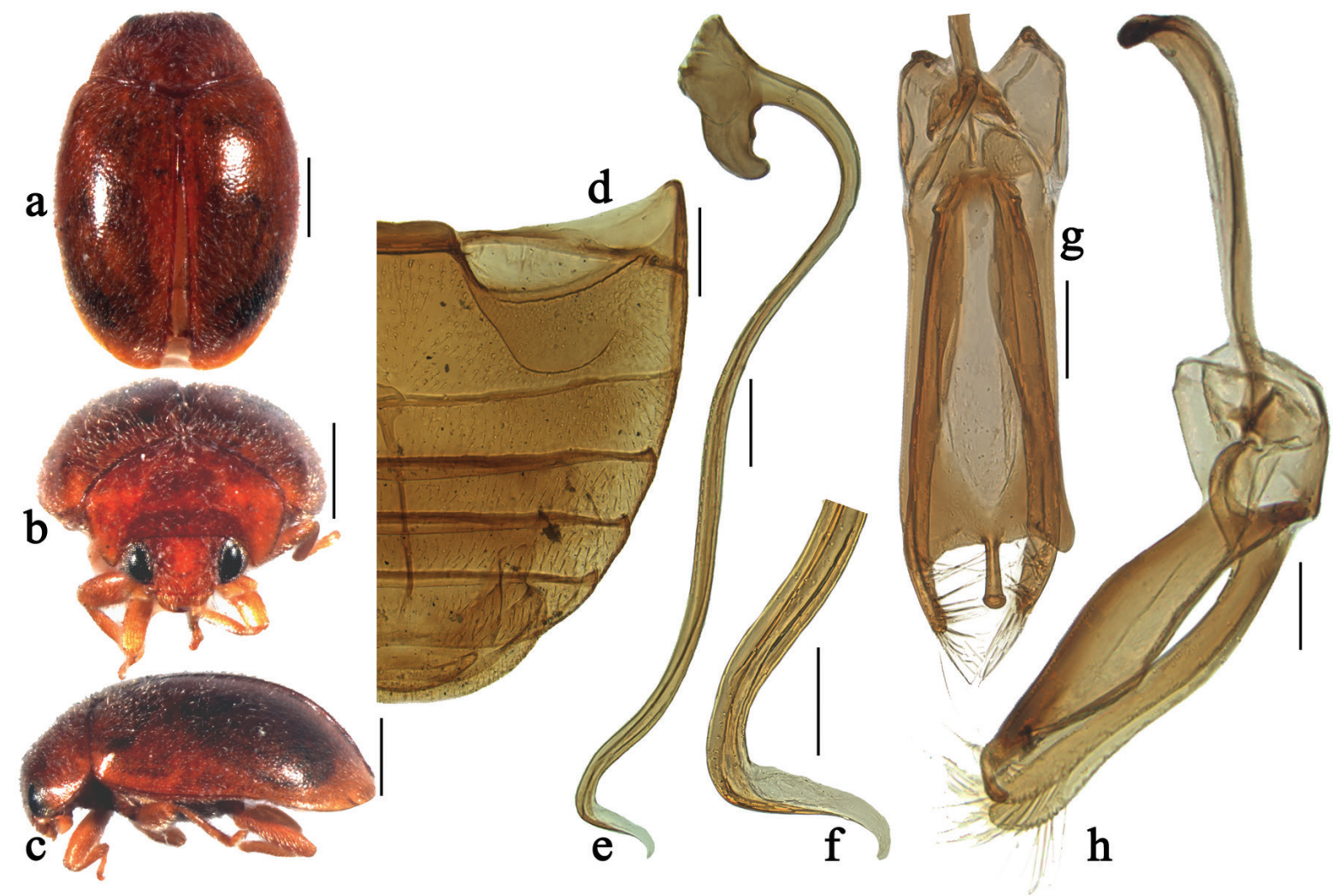

Figure 1. Scymnus (Parapullus) hastatus sp. n.: a dorsal view; b anterior view; c lateral view; $\mathbf{d}$ abdomen; e penis; $\mathbf{f}$ apex of penis; $\mathbf{g}$ tegmen, ventral view; $\mathbf{h}$ tegmen, lateral view. Scale bars: $\mathbf{a}-\mathbf{c} 0.5 \mathrm{~mm}, \mathbf{d} 0.2 \mathrm{~mm}, \mathbf{e}-\mathbf{h} 0.1 \mathrm{~mm}$.

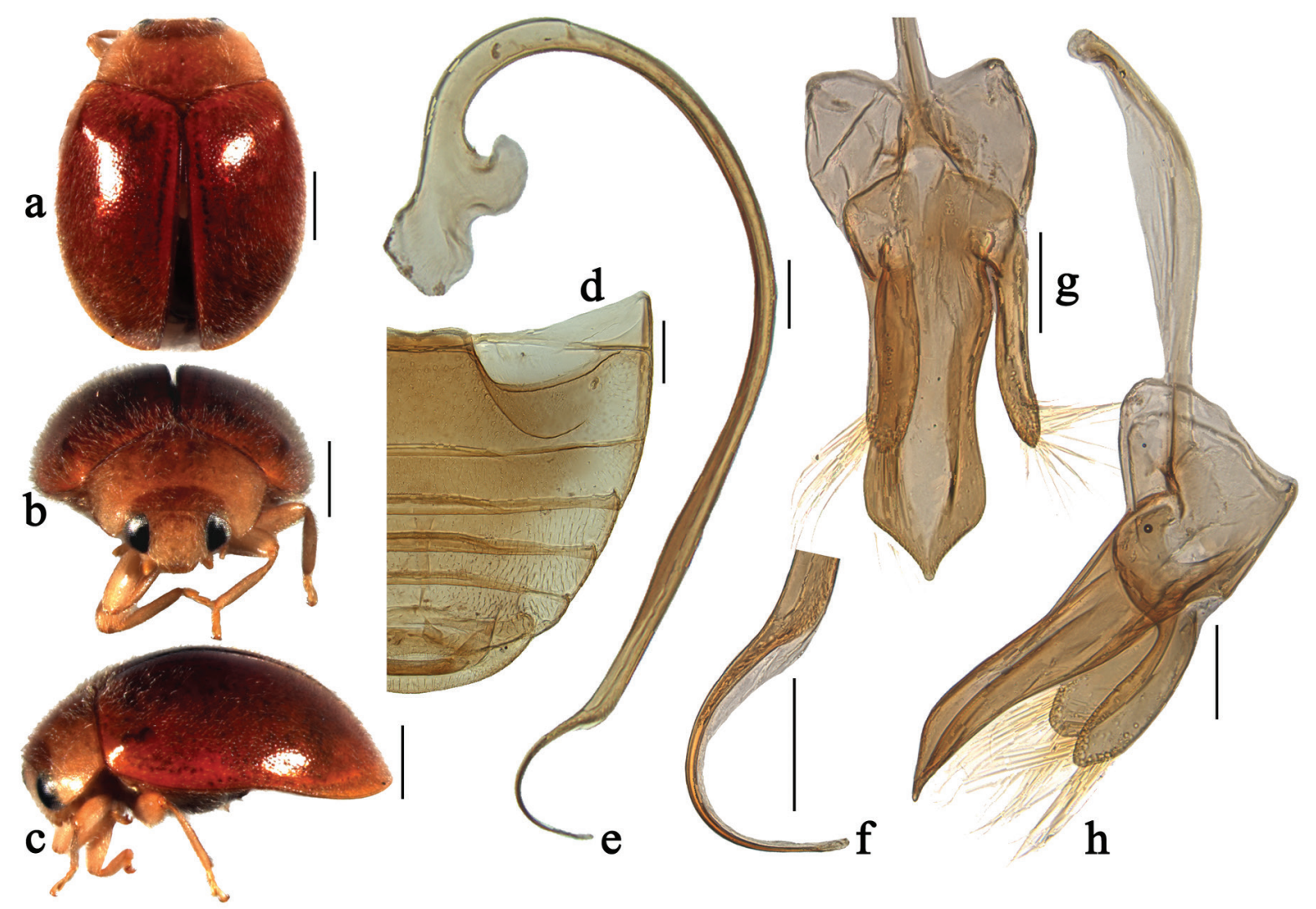

Figure 2. Scymnus (Parapullus) baxianshanensis sp. n.: a dorsal view; $\mathbf{b}$ anterior view; $\mathbf{c}$ lateral view; $\mathbf{d}$ abdomen; e penis; $\mathbf{f}$ apex of penis; $\mathbf{g}$ tegmen, ventral view; $\mathbf{h}$ tegmen, lateral view. Scale bars: $\mathbf{a}-\mathbf{c} 0.5 \mathrm{~mm}, \mathbf{d} 0.2 \mathrm{~mm}, \mathbf{e}-\mathbf{h} 0.1 \mathrm{~mm}$. 
shaped (Fig. 2f). Tegmen stout (Figs 2g-h) with penis guide slightly constricted at middle part, expanding toward apex, then tapering abruptly to blunt apex in ventral view (Fig. 2g). Parameres narrow, as long as half length of penis guide, densely covered with two groups of long setae at apices (Fig. 2h).

Female similar to male except for sexual characters.

Type materials. Holotype: male, No. SCAU (E) 11532, China: Tianjin: Baxianshan National Nature Reserve, Ji County, $40^{\circ} 11.27^{\prime} \mathrm{N}, 117^{\circ} 33.19^{\prime} \mathrm{E}$, ca $500 \mathrm{~m}$, 14. VII. 2011, Chen XS leg. Paratypes (3): $1 \overbrace{}^{\Uparrow} 2$ q with same data as holotype.

Distribution. China (Tianjin).

Etymology. The specific epithet refers to its type locality, Baxianshan National Nature Reserve, Tianjin.

\section{Scymnus (Parapullus) laojielingensis sp. $\mathrm{n}$.}

http://zoobank.org/6457D29C-A8B3-440B-B5E6-24B57BA824B4 Figs 3, 10

Diagnosis. This species is similar to Scymnus (Parapullus) parallelicus Chen, Ren \& Wang, 2012 in general appearance and male genitalia, but can be distinguished from it by having strongly sinuated apex of penis with membranous appendage (Fig. 3f), the apical $1 / 4$ length of parameres covered with several long setae at inner sides in lateral view (Fig. $3 \mathrm{~h}$ ), and the area enclosed by the abdominal postcoxal lines with coarse punctures (Fig. 3d).

Description. TL: $2.21-2.38 \mathrm{~mm}$, TW: $1.58-1.71 \mathrm{~mm}$, TH: $1.01-1.16 \mathrm{~mm}, \mathrm{TL} / \mathrm{TW}: 1.39-1.40$, PL/PW: $0.51-$ 0.52, EL/EW: 1.08-1.12, HW/PW: 0.56, PW/EW: 0.72.

Body elongate oval, moderately convex, entirely reddish brown, dorsum covered with white pubescence (Fig. 3a-c).

Head with fine frontal punctures, as large as eye facets, 0.5-1.0 diameter apart. Eyes densely faceted, interocular distance 0.47 times head width. Pronotal punctures similar to those on frons, 1.0-2.0 diameters apart. Surface of elytra with punctures larger than those on pronotum, separated by 2.0-3.0 diameters. Prosternal process trapezoidal, 2.5 times as long as its width at base; with lateral carinae distinct, extending to anterior margin of prosternum, distinctly convergent anteriorly. Abdominal postcoxal lines weakly recurved and distinctly incomplete laterally (Fig. 3d), reaching 5/6 length of abdominal ventrite 1 , area enclosed by lines coarsely punctate, narrowly smooth along line. Abdominal ventrite 5 in male with apex rounded.

Male genitalia: penis stout (Fig. 3e). Penis capsule with small inner arm and large outer arm. Apex of penis strongly sinuated with membranous appendage (Fig. 3f). Tegmen stout (Fig. $3 \mathrm{~g}-\mathrm{h}$ ) with penis guide with parallel sides from base to $3 / 4$ length, then tapering gradually to blunt apex in ventral view (Fig. 3g) and its apex slightly curved outwardly in lateral view (Fig. 3h). Parameres longer than half length of penis guide, densely covered with a group of long setae at apices, and its apical 1/4 length covered with several stout setae at inner sides (Fig. 3h).

Female externally similar to male but with abdominal ventrite 5 truncate apically.

Type materials. Holotype: male, No. SCAU (E) 11534, China: Henan: Laojieling National Nature Reserve, Xixia County, Nanyang City, 33³7.63’N, $111^{\circ} 45.85^{\prime} \mathrm{E}$, ca $1400 \mathrm{~m}, 9$. VII. 2009, Chen XS leg. Paratypes (3): $1 \delta^{\lambda} 2 q$ with same data as holotype.

Distribution. China (Henan).

Etymology. The specific epithet refers to its type locality, Laojieling National Nature Reserve, Henan Province.

\section{Scymnus (Parapullus) annuliformis sp. $\mathbf{n}$.}

http://zoobank.org/0F93276E-3C30-4E20-A485-8705A4B5F300 Figs 4, 10

Diagnosis. This species is similar to Scymnus (Parapullus) parallelicus Chen, Ren \& Wang, 2012 in general appearance and male genitalia, but can be separated from it by having slender, ring shaped apex of penis (Fig. 4f) and the abdominal postcoxal lines strongly recurved toward base of ventrite (Fig. 4d). It also resembles Scymnus (Parapullus) malleatus Chen, Ren \& Wang, 2012, particularly the ring shaped apex of penis, but can be recognized from it by having narrow and short parameres (Fig. 4h) and the different shape of penis capsule.

Description. TL: $2.28-2.34 \mathrm{~mm}$, TW: $1.58-1.71 \mathrm{~mm}$, TH: 1.06-1.15 mm, TL/TW: 1.37-1.44, PL/PW: 0.510.53, EL/EW: 1.07-1.13, HW/PW: 0.60-0.61, PW/EW: $0.67-0.71$.

Body oval, moderately convex, entirely reddish brown, dorsum covered with white pubescence (Fig. $4 a-c)$.

Head with fine frontal punctures, as large as eye facets, 1.0-2.0 diameters apart. Eyes densely faceted, interocular distance 0.49 times head width. Pronotal punctures larger than those on frons, 1.0-2.0 diameters apart. Surface of elytra with punctures larger than those on pronotum, separated by 2.0-3.0 diameters. Prosternal process trapezoidal, 2.5 times as long as its width at base; with lateral carinae distinct, extending to anterior margin of prosternum, slightly convergent anteriorly. Abdominal postcoxal lines strongly recurved and distinctly incomplete laterally (Fig. 4d), reaching 5/6 length of abdominal ventrite 1, area enclosed by lines finely punctate, broadly smooth along line. Abdominal ventrite 5 in both sexes with apex truncate.

Male genitalia: penis moderately stout (Fig. 4e). Penis capsule with small inner arm and large outer arm. Apex of penis slender, ring shaped (Fig. 4f). Tegmen stout (Fig. $4 \mathrm{~g}-\mathrm{h}$ ) with penis guide parallel sided from base to $3 / 4$ length, then tapering gradually to blunt apex in ventral view (Fig. 4g). Parameres stout with obliquely truncate apex, longer than half length of penis guide, densely covered with two groups of long setae at apices (Fig. 4h). 


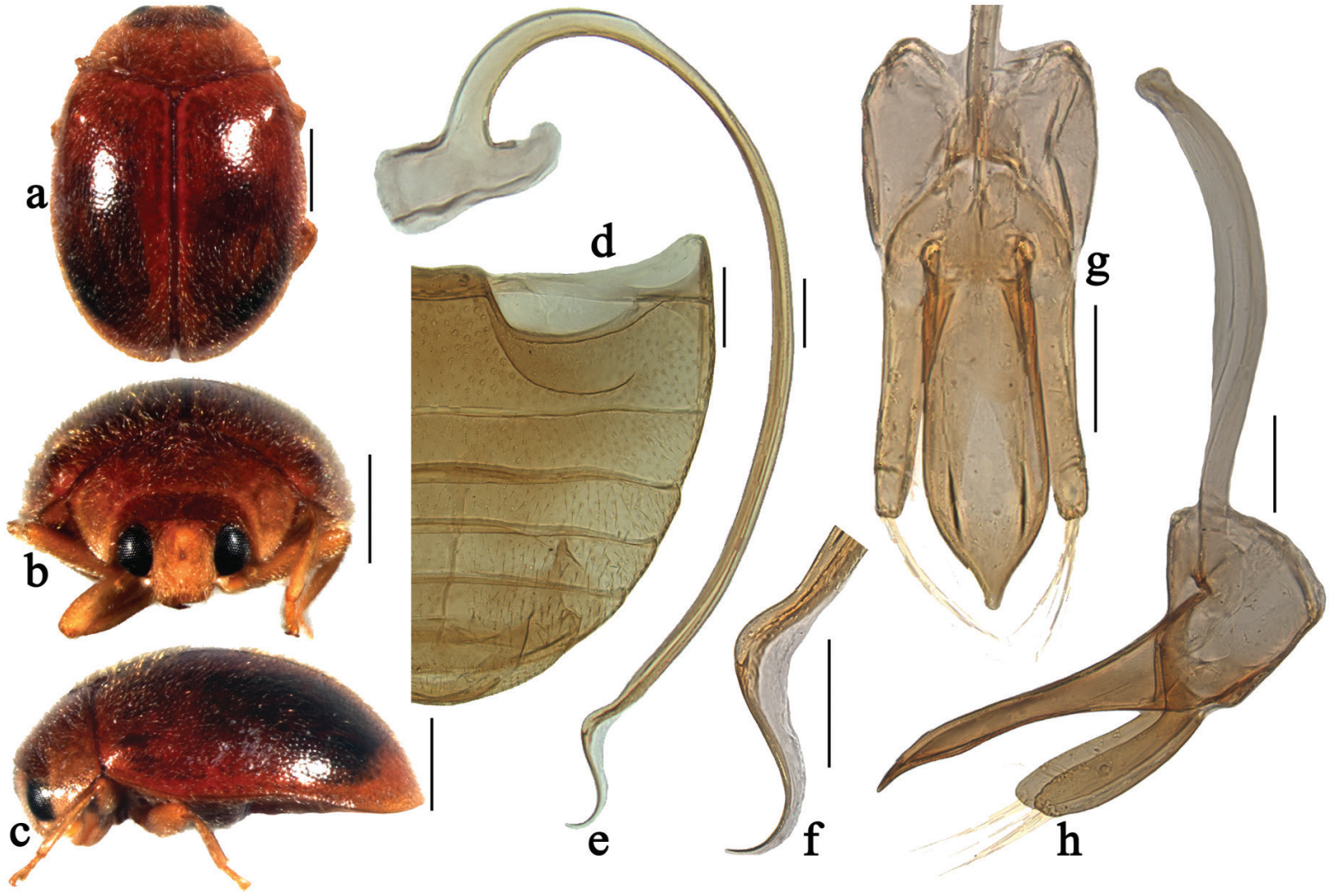

Figure 3. Scymnus (Parapullus) laojielingensis sp. n.: a dorsal view; b anterior view; c lateral view; $\mathbf{d}$ abdomen; e penis; $\mathbf{f}$ apex of penis; $\mathbf{g}$ tegmen, ventral view; $\mathbf{h}$ tegmen, lateral view. Scale bars: a-c $0.5 \mathrm{~mm}, \mathbf{d} 0.2 \mathrm{~mm}, \mathbf{e}-\mathbf{h} 0.1 \mathrm{~mm}$.
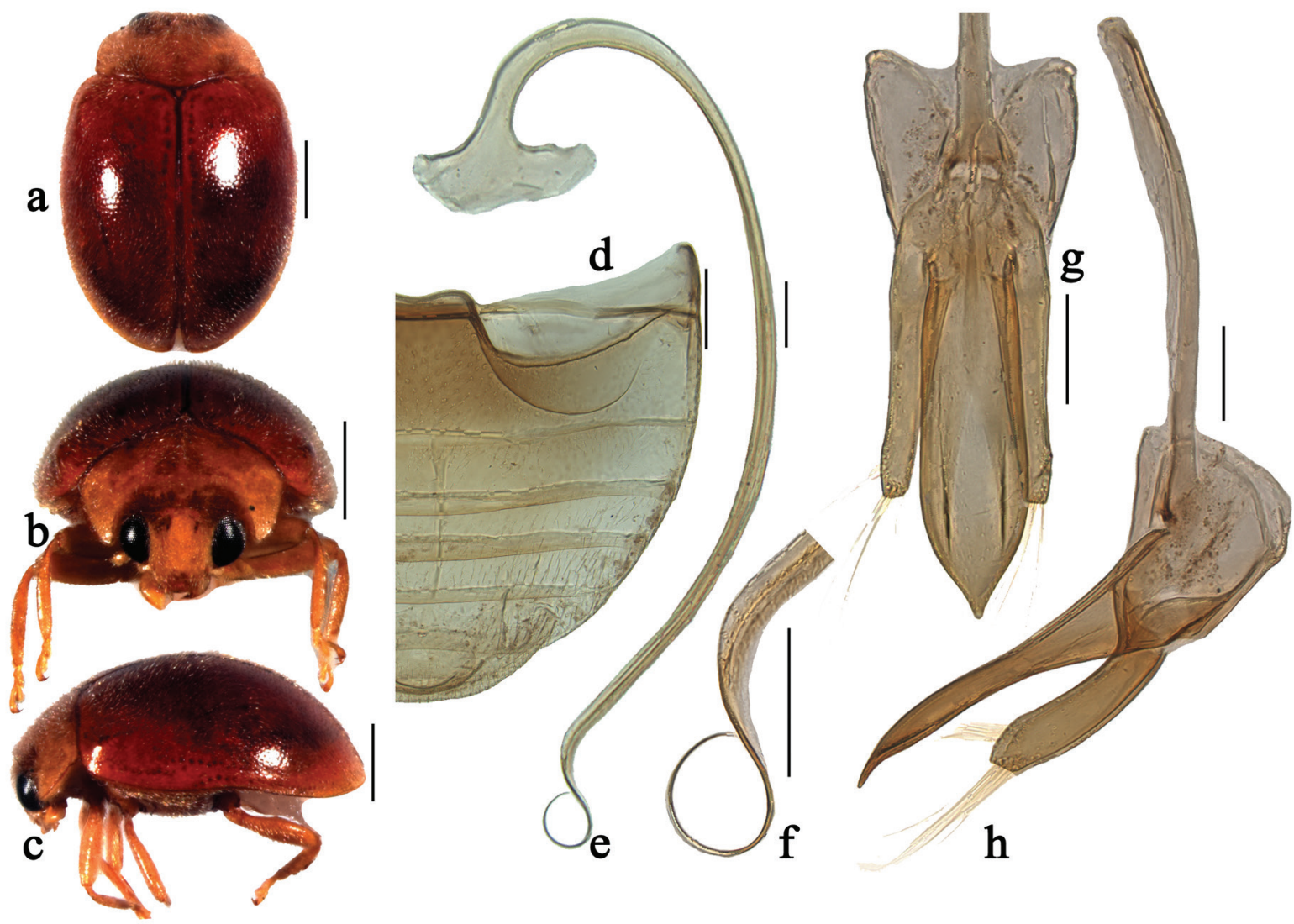

Figure 4. Scymnus (Parapullus) annuliformis sp. n.: a dorsal view; $\mathbf{b}$ anterior view; $\mathbf{c}$ lateral view; $\mathbf{d}$ abdomen; $\mathbf{e}$ penis; $\mathbf{f}$ apex of penis; $\mathbf{g}$ tegmen, ventral view; $\mathbf{h}$ tegmen, lateral view. Scale bars: $\mathbf{a}-\mathbf{c} 0.5 \mathrm{~mm}, \mathbf{d} 0.2 \mathrm{~mm}, \mathbf{e}-\mathbf{h} 0.1 \mathrm{~mm}$. 
Female similar to male except for sexual characters.

Type materials. Holotype: male, No. SCAU (E) 11527 , China: Anhui: Hongshan, Yaoluoping National Nature Reserve, Yuexi County, $31^{\circ} 0.85^{\prime} \mathrm{N}, 116^{\circ} 8.67^{\prime} \mathrm{E}$, ca 800 m, 30. IX. 2010, Wang XM leg. Paratypes (9): Anhui: $1 \hat{\jmath}$ with same data as holotype. $1 \hat{\jmath}$, Yaoluoping National Nature Reserve, Yuexi County, 3058.95'N, $116^{\circ} 4.83^{\prime} \mathrm{E}$, ca 1000 m, 28. IX. 2010, Li WJ leg. Tibet: 1 , Cibagou National Nature Reserve, Chayu County, 28³3.69’ N, 975.10'E, ca 2000 m, 13. X. 2007, Chen XS leg. 2ㅇ, Xiachayu Town, Chayu County, $28^{\circ} 30.04^{\prime} \mathrm{N}, 9^{\circ} 0.84^{\prime} \mathrm{E}$, ca $1800 \mathrm{~m}, 14$. X. 2007, Chen XS leg. 1ふ̄, Xiayadong Village, Yadong County, $28^{\circ} 29.29^{\prime} \mathrm{N}, 9^{\circ} 1.36^{\prime} \mathrm{E}$, ca 2800 m, 29-30. IX. 2009, Chen XS leg. 19, Motuo County, Linzhi City, $29^{\circ} 19.30^{\prime} \mathrm{N}, 9^{\circ} 18.33^{\prime} \mathrm{E}$, ca $760 \mathrm{~m}, 17$. X. 2009, Chen XS leg. 1, Lebu Village, Cuona County, $27^{\circ} 48.63^{\prime} \mathrm{N}, 91^{\circ} 44.98^{\prime} \mathrm{E}$, ca 2400 m, 24. X. 2011, Li WJ leg. $1 \jmath^{\lambda}$, Mama Village, Cuona County, $27^{\circ} 47.44^{\prime} \mathrm{N}$, 91ํ⒍56’E, ca 2800 m, 25. X. 2011, Huo LZ leg.

Distribution. China (Anhui, Tibet).

Etymology. The specific epithet refers to its penis with ring shaped apex.

\section{Scymnus (Parapullus) papillatus sp. $\mathbf{n}$.}

http://zoobank.org/54FE83B5-3AD8-4D2A-8373-E5B0180B5615 Figs 5, 11

Diagnosis. This species is similar to Scymnus (Parapullus) solus Chen, Ren \& Wang, 2012 in general appearance and male genitalia, but can be separated from it by having a papilla bearing a stout seta at the apical 1/3 length of paramere (Fig. 5h).

Description. TL: $1.98-2.36 \mathrm{~mm}$, TW: $1.39-1.66 \mathrm{~mm}$, TH: 0.92-1.09 mm, TL/TW: 1.42, PL/PW: 0.50-0.55, EL/ EW: 1.09-1.12, HW/PW: 0.59-0.60, PW/EW: 0.70-0.73.

Body elongate oval, moderately convex, dorsum covered with white pubescence (Fig. 5a-c). Head, antennae and mouthparts brown. Pronotum dark brown. Scutellum black. Elytra black with apical 1/4 brown. Prothoracic hypomeron and prosternum brown. Mesoventrite, metaventrite and elytral epipleura black. Legs brown.

Head with fine frontal punctures, as large as eye facets, 0.5-1.0 diameter apart. Eyes densely faceted, interocular distance 0.50 times head width. Pronotal punctures larger than those on frons, 1.5-3.0 diameters apart. Surface of elytra with punctures as large as those on pronotum, separated by 1.0-2.0 diameters. Prosternal process trapezoidal, 2.3 times as long as its width at base; with lateral carinae distinct, extending to anterior margin of prosternum, distinctly convergent anteriorly. Abdominal postcoxal lines weakly recurved and distinctly incomplete laterally (Fig. 5d), nearly extending to posterior margins of abdominal ventrite 1 , area enclosed by lines finely punctate, narrowly smooth along line. Abdominal ventrite 5 in male with apex truncate.

Male genitalia: penis stout and long (Fig. 5e). Penis capsule with outer arm large and inner arm strongly curved. Apex of penis unevenly curved, forming a large hook (Fig. 5f). Tegmen stout (Fig. 5g-h) with penis guide narrowest at base, expanding toward apex, then tapering abruptly to blunt apex in ventral view (Fig. 5g). Parameres obliquely truncated apically, longer than half length of penis guide, densely covered with a group of long setae at apices, and its apical $1 / 3$ length with a papilla bearing a stout seta on inner side (Fig. 5h).

Female externally similar to male but with abdominal ventrite 5 rounded apically.

Type materials. Holotype: male, No. 20050319043, China: Guangdong: Xiaohuangshan, Nanling National Nature Reserve, Shaoguan City, 24⒌76'N, $113^{\circ} 2.83^{\prime} \mathrm{E}$, ca 800 m, 1. X. 2004, Ren SX leg. Paratypes (12): Guangdong: $1 \hat{\jmath}$ with same data as holotype except "Chen JJ leg". Hunan: $1 \jmath^{\lambda}$, Mangshan National Nature Reserve, Yizhang County, 2458.83'N, 112 53.14'E, ca 700 m, 2. X. 2004, Ren SX leg. Tianjin: $3{ }^{\lambda} 6$, Baxianshan National Nature Reserve, Ji County, $40^{\circ} 11.27^{\prime} \mathrm{N}, 117^{\circ} 33.19^{\prime} \mathrm{E}$, ca 500 m, 14. VII. 2011, Chen XS leg. Shanxi: 1 $\jmath^{\lambda}$, Lishan National Nature Reserve, Yuanqu County, $35^{\circ} 28.39^{\prime} \mathrm{N}, 112^{\circ} 9.45^{\prime} \mathrm{E}$, ca 1200 m, 3. VIII. 2011, Chen XS leg.

Distribution. China (Shanxi, Tianjin, Hunan, Guangdong).

Etymology. The specific epithet refers to its paramere with a papilla on the inner side of the apical 1/3 length.

\section{Scymnus (Parapullus) dichotomus sp. $\mathbf{n}$.}

http://zoobank.org/8D650875-A228-462F-9A0A-FAC4133A1697 Figs 6, 11

Diagnosis. This species is similar to Scymnus (Parapullus) aduncatus Chen, Ren \& Wang, 2012 in general appearance, but can be distinguished from it by having robust basal part of penis guide in lateral view (Fig. 6h) and the blunt apex in lateral view (Fig. 6g).

Description. TL: $2.16 \mathrm{~mm}$, TW: $1.46 \mathrm{~mm}$, TH: 0.97 mm, TL/TW: 1.48, PL/PW: 0.52, EL/EW: 1.14, HW/PW: 0.63, PW/EW: 0.71 .

Body elongate oval, moderately convex, dorsum covered with white pubescence (Figs 6a-c). Head, antennae and mouthparts brown. Pronotum yellowish brown. Scutellum black. Elytra black with apical 1/6 yellowish brown. Prothoracic hypomeron and prosternum yellowish brown. Mesoventrite, metaventrite and elytral epipleura black. Legs brown.

Head with fine frontal punctures, as large as eye facets, 1.0-2.0 diameters apart. Eyes densely faceted, interocular distance 0.49 times head width. Pronotal punctures larger than those on frons, 1.0-2.0 diameters apart. Surface of elytra with punctures similar to those on pronotum, separated by 2.0-3.0 diameters. Prosternal process trapezoidal, 2 times as long as its width at base; with lateral carinae distinct, extending to anterior margin of prosternum, slightly convergent anteriorly. Abdominal postcoxal lines weakly recurved and distinctly incomplete laterally (Fig. 


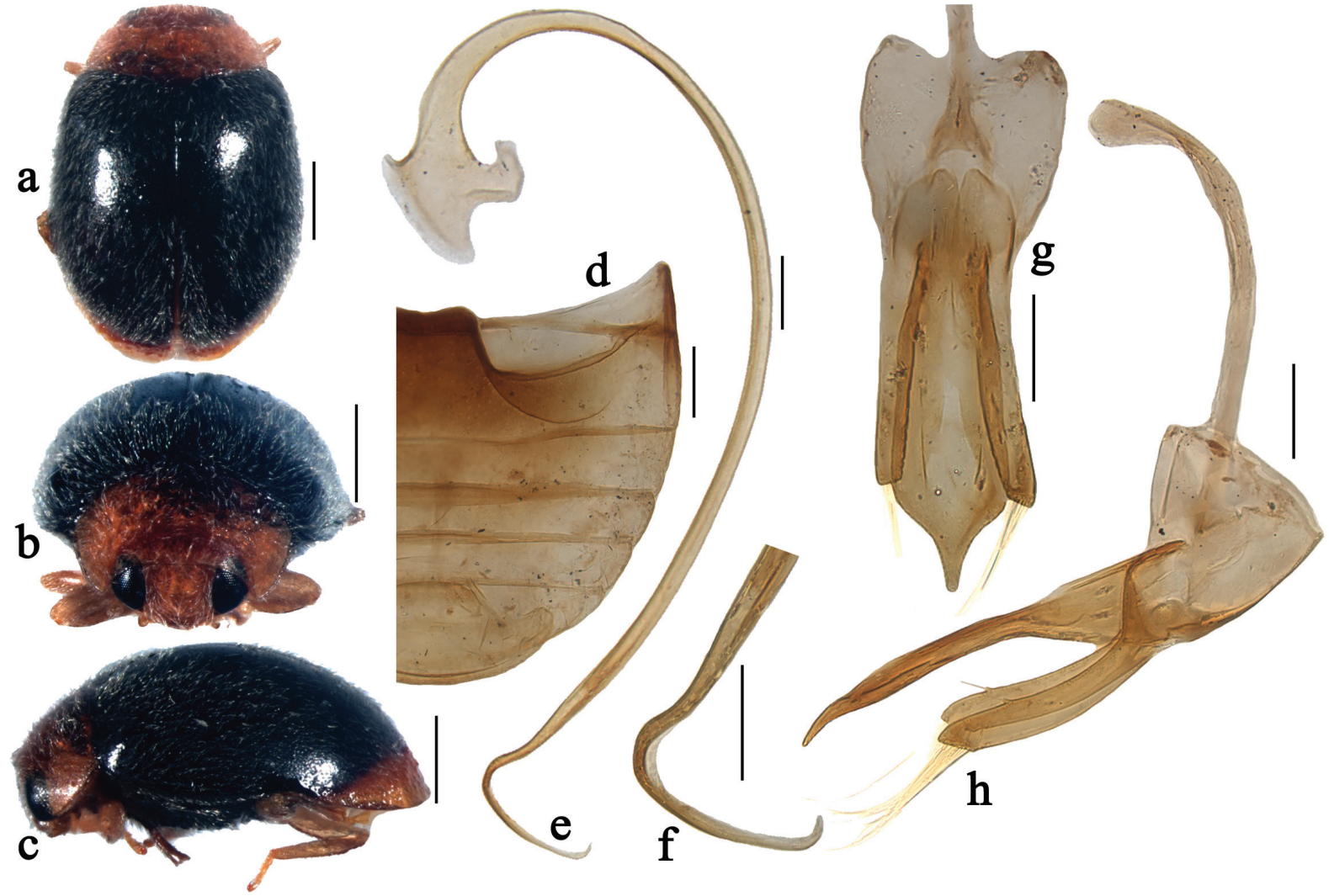

Figure 5. Scymnus (Parapullus) papillatus sp. n.: a dorsal view; $\mathbf{b}$ anterior view; c lateral view; $\mathbf{d}$ abdomen; e penis; $\mathbf{f}$ apex of penis; $\mathbf{g}$ tegmen, ventral view; h tegmen, lateral view. Scale bars: a-c $0.5 \mathrm{~mm}, \mathbf{d} 0.2 \mathrm{~mm}, \mathbf{e}-\mathbf{h} 0.1 \mathrm{~mm}$.
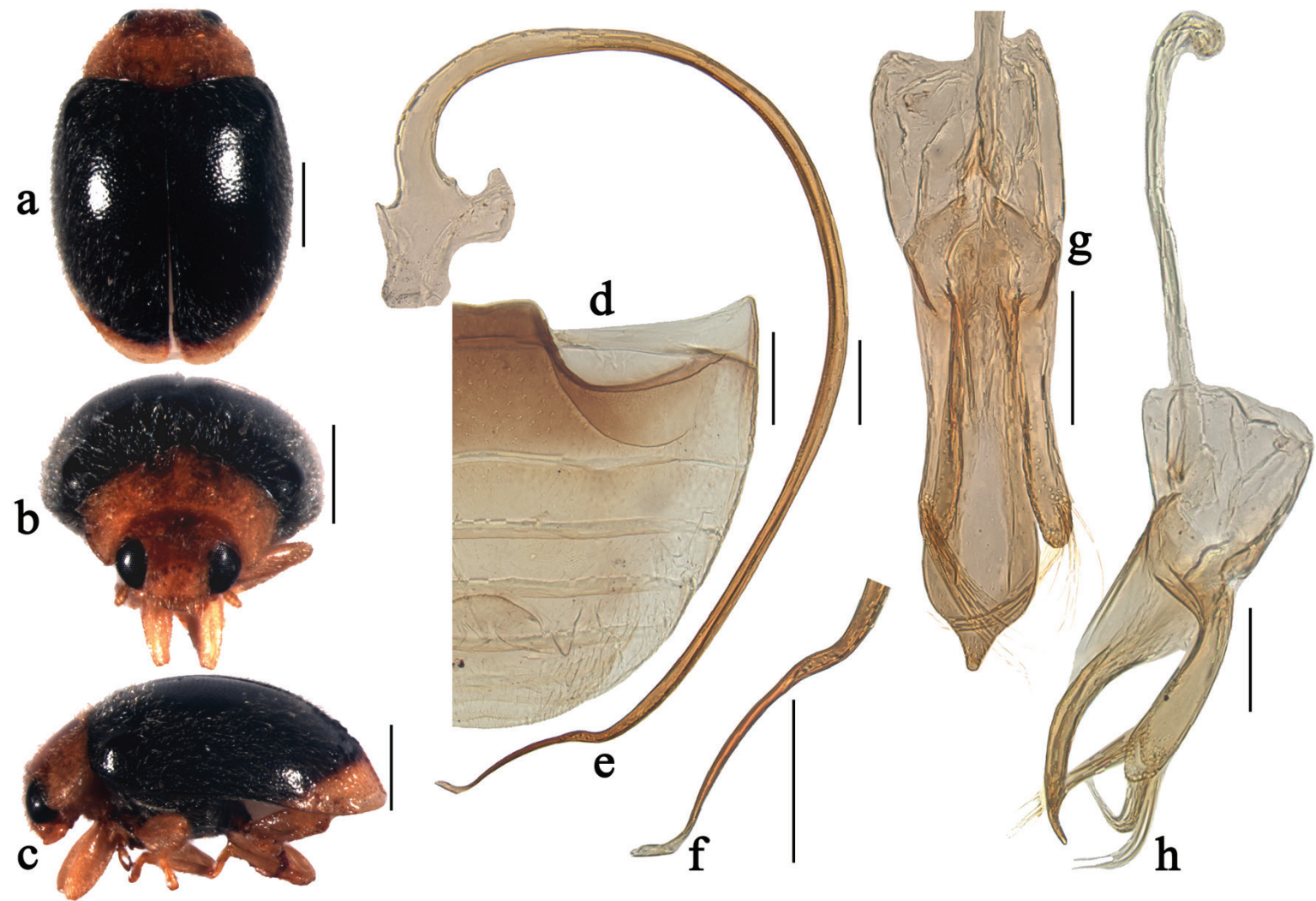

Figure 6. Scymnus (Parapullus) dichotomus sp. n.: a dorsal view; b anterior view; c lateral view; d abdomen; e penis; $\mathbf{f}$ apex of penis; $\mathbf{g}$ tegmen, ventral view; $\mathbf{h}$ tegmen, lateral view. Scale bars: $\mathbf{a}-\mathbf{c} 0.5 \mathrm{~mm}, \mathbf{d} 0.2 \mathrm{~mm}, \mathbf{e}-\mathbf{h} 0.1 \mathrm{~mm}$. 
$6 \mathrm{~d})$, reaching $4 / 5$ length of abdominal ventrite 1 , area enclosed by lines finely punctate, broadly smooth along line. Abdominal ventrite 5 in male with apex truncate.

Male genitalia: penis slender (Fig. 6e). Penis capsule stout with outer arm large and inner arm strongly curved upwardly. Apex of penis simple (Fig. 6f). Tegmen stout (Figs $6 \mathrm{~g}-\mathrm{h}$ ) with penis guide narrowest at base, expanding toward apex, then tapering abruptly to blunt apex in ventral view (Fig. 6g) and strongly curved outwardly in lateral view (Fig. 6h). Parameres slightly constricted at base, distinctly shorter than penis guide, densely covered with two groups of long setae at apices (Fig. 6h).

Female unknown.

Type material. Holotype: male, No. SCAU (E) 11388, China: Yunnan: Xujiaba, Ailaoshan National Nature Reserve, Jingdong County, $24^{\circ} 32.77^{\prime} \mathrm{N}, 101^{\circ} 01.69^{\prime} \mathrm{E}$, ca 2500 m, 17. VIII. 2013, Chen XS leg.

Distribution. China (Yunnan).

Etymology. The specific epithet refers to its apex of paramere densely covered with two groups of long setae.

\section{Scymnus (Parapullus) shenmuensis sp. $\mathbf{n}$.}

http://zoobank.org/99B80354-E9DD-4153-930A-27AB9F692328 Figs 7,12

Diagnosis. This species is similar to Scymnus (Parapullus) secula Yang, 1978 in general appearance and male genitalia, but can be separated from it by the brown pronotum with a large black marking (Fig. 7a-b) and the apex of penis stout, hook-shaped (Fig. 7f).

Description. TL: $2.18 \mathrm{~mm}$, TW: $1.46 \mathrm{~mm}$, TH: 0.98 mm, TL/TW: 1.49, PL/PW: 0.46, EL/EW: 1.20, HW/PW: 0.57, PW/EW: 0.77 .

Body elongate oval, slightly convex, dorsum covered with white pubescence (Figs $7 \mathrm{a}-\mathrm{c}$ ). Head, antennae and mouthparts dark brown. Pronotum brown with a large black marking. Scutellum black. Elytra black with apical 1/6 yellowish brown. Prothoracic hypomeron and prosternum brown. Mesoventrite, metaventrite and elytral epipleura black. Legs brown.

Head with fine frontal punctures, slightly larger than eye facets, 0.5-1.0 diameter apart. Eyes densely faceted, interocular distance 0.50 times head width. Pronotal punctures as large as those on frons, 1.0-2.0 diameters apart. Surface of elytra with punctures larger than those on pronotum, separated by 2.0-3.0 diameters. Prosternal process trapezoidal, 2 times as long as its width at base; with lateral carinae distinct, extending to anterior margin of prosternum, slightly convergent anteriorly. Abdominal postcoxal lines strongly recurved and distinctly incomplete laterally (Fig. 7d), reaching 5/6 length of abdominal ventrite 1, area enclosed by lines irregularly punctate, narrowly smooth along line. Abdominal ventrite 5 in male with apical margin shallowly emarginated medially.

Male genitalia: penis stout (Fig. 7e). Penis capsule with small inner arm and large outer arm. Apex of penis stout with membranous appendage, hook-shaped (Fig. 7f). Teg- men stout (Figs $7 \mathrm{~g}-\mathrm{h}$ ) with penis guide narrowest at base, expanding toward apex, then tapering abruptly to blunt apex in ventral view (Fig. 7g) and its apex slightly curved outwardly in lateral view (Fig. 7h). Parameres slightly curved at base, distinctly shorter than penis guide, densely covered with two groups of long setae at apices (Fig. 7h).

Female unknown.

Type material. Holotype: male, No. SCAU (E) 11455 , China: Taiwan: Shenmu Railway Station, Alishan Mountains, Jiayi County, $23^{\circ} 31.12^{\prime} \mathrm{N}, 120^{\circ} 48.37^{\prime} \mathrm{E}$, ca 2200 m, 23. X. 2012, Chen XS leg.

Distribution. China (Taiwan).

Etymology. The specific epithet refers to its type locality, Shenmu Railway Station in Alishan Mountains, Taiwan.

\section{Scymnus (Parapullus) yanzigouensis sp. $\mathrm{n}$.}

http://zoobank.org/1CC0B157-15A9-4F86-85AA-29FB14857F92 Figs 8, 12

Diagnosis. This species is similar to Scymnus (Parapullus) nanlingicus Chen, Ren \& Wang, 2012 in general appearance and male genitalia, but can be separated from it by having broad area enclosed by abdominal postcoxal lines (Fig. 8d) and the parameres narrowest at base, expanding toward apex in lateral view (Fig. $8 \mathrm{~h}$ ).

Description. TL: $2.20-2.42 \mathrm{~mm}$, TW: $1.52-1.67 \mathrm{~mm}$, TH: 0.99-1.05 mm, TL/TW: 1.45, PL/PW: 0.51, EL/EW: 1.13-1.14, HW/PW: 0.56-0.58, PW/EW: 0.73-0.74.

Body oval, moderately convex, dorsum covered with white pubescence (Fig. 8a-c). Head, antennae and mouthparts brown. Pronotum yellowish brown. Scutellum dark brown. Elytra black with apical 1/4 yellowish brown. Prothoracic hypomeron and prosternum yellowish brown. Mesoventrite, metaventrite and elytral epipleura black. Legs brown.

Head with fine frontal punctures, as large as eye facets, 0.5-1.0 diameters apart. Eyes densely faceted, interocular distance 0.47 times head width. Pronotal punctures similar to those on frons, 1.0-2.0 diameters apart. Surface of elytra with punctures larger than those on pronotum, separated by 2.0-3.0 diameters. Prosternal process rectangular, 2 times as long as its width at base; with lateral carinae distinct, parallel, extending to anterior margin of prosternum. Abdominal postcoxal lines strongly recurved and distinctly incomplete laterally (Fig. 8d), reaching 7/8 length of abdominal ventrite 1 , area enclosed by lines irregularly punctate, broadly smooth along line. Abdominal ventrite 5 in male with apex truncate.

Male genitalia: penis stout (Fig. 8e). Penis capsule with outer arm stout and inner arm strongly curved, hookshaped. Apex of penis simple (Fig. 8f). Tegmen stout (Fig. $8 \mathrm{~g}-\mathrm{h}$ ) with penis guide parallel sided from base to $4 / 5$ length, then tapering abruptly to blunt apex in ventral view (Fig. 8g). Parameres narrowest at base, expanding toward apex, distinctly shorter than penis guide, densely covered with two groups of long setae at apices (Fig. 8h).

Female unknown. 

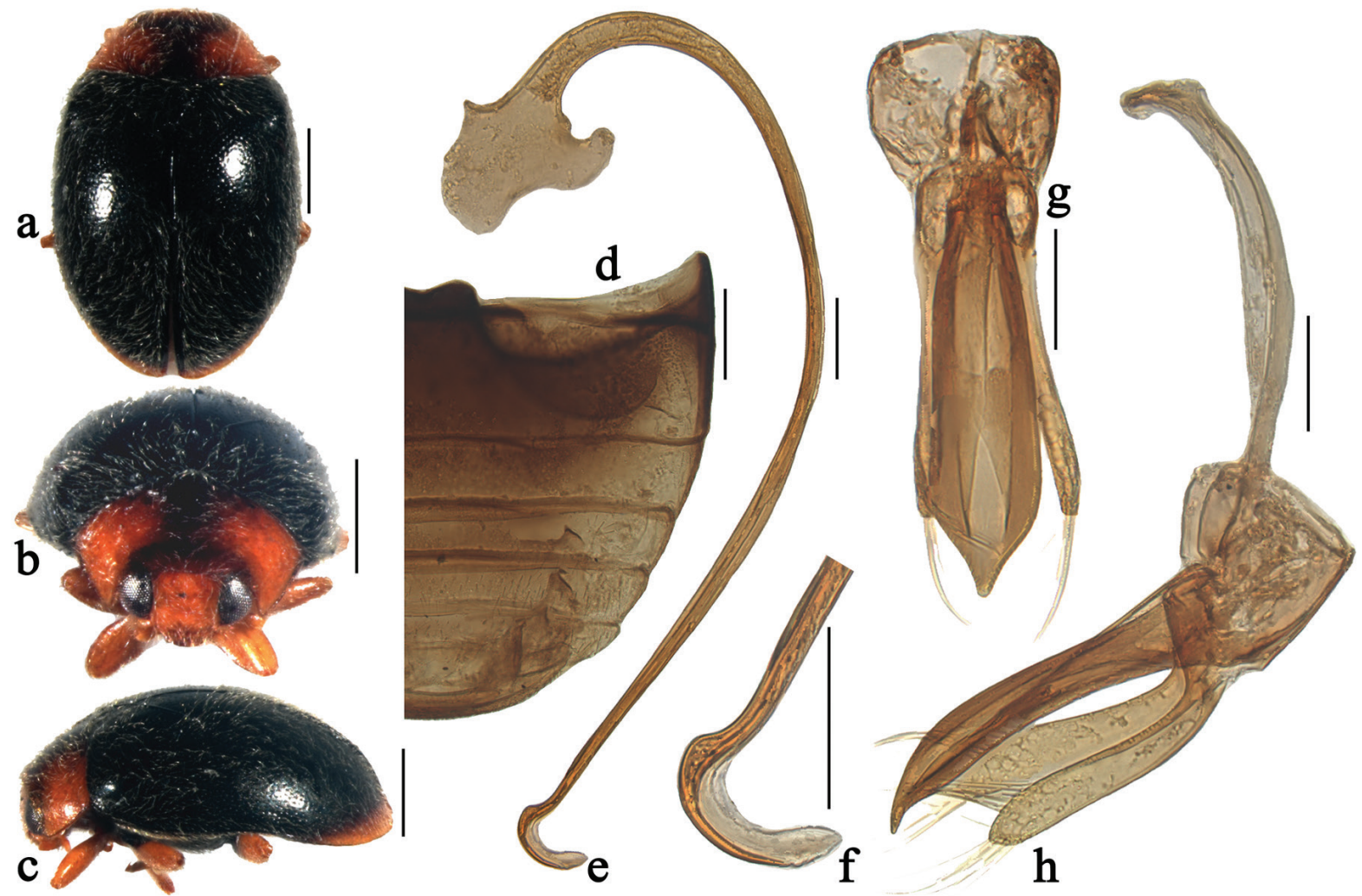

Figure 7. Scymnus (Parapullus) shenmuensis sp. n.: a dorsal view; b anterior view; c lateral view; $\mathbf{d}$ abdomen; e penis; $\mathbf{f}$ apex of penis; $\mathbf{g}$ tegmen, ventral view; $\mathbf{h}$ tegmen, lateral view. Scale bars: a-c $0.5 \mathrm{~mm}, \mathbf{d} 0.2 \mathrm{~mm}, \mathbf{e}-\mathbf{h} 0.1 \mathrm{~mm}$.

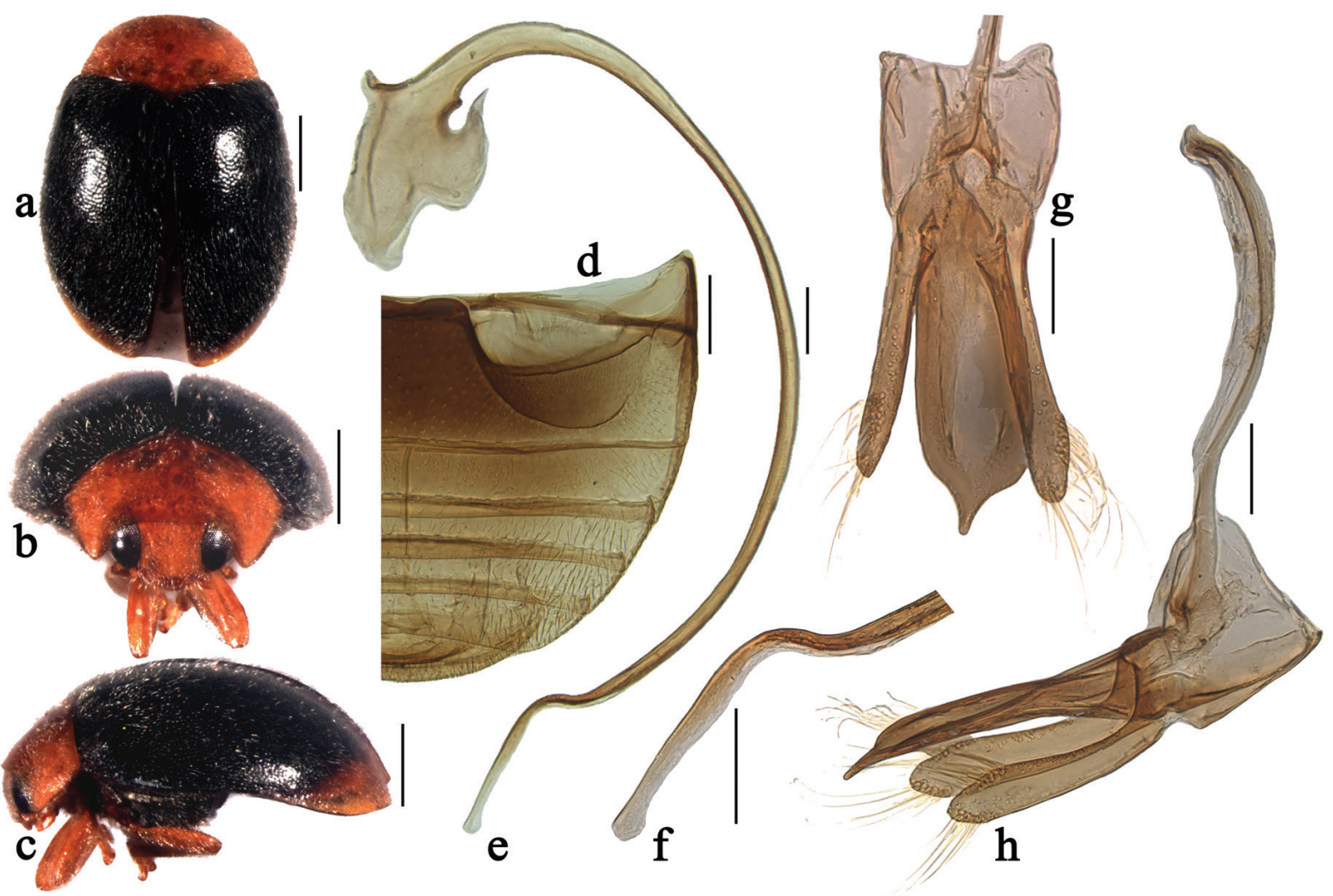

Figure 8. Scymnus (Parapullus) yanzigouensis sp. n.: a dorsal view; $\mathbf{b}$ anterior view; c lateral view; $\mathbf{d}$ abdomen; e penis; $\mathbf{f}$ apex of penis; $\mathbf{g}$ tegmen, ventral view; $\mathbf{h}$ tegmen, lateral view. Scale bars: a-c $0.5 \mathrm{~mm}, \mathbf{d ~} 0.2 \mathrm{~mm}, \mathbf{e}-\mathbf{h} 0.1 \mathrm{~mm}$. 


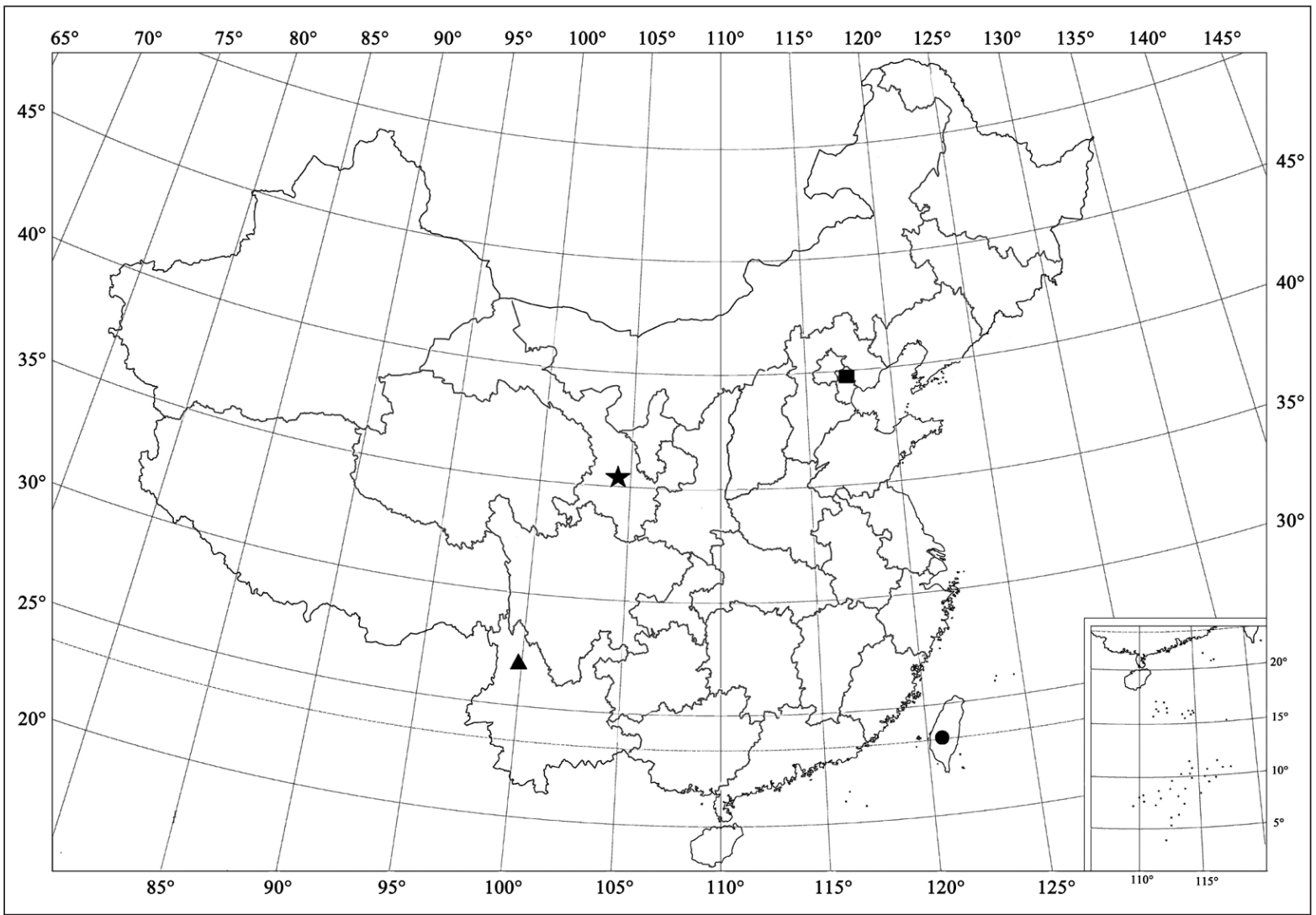

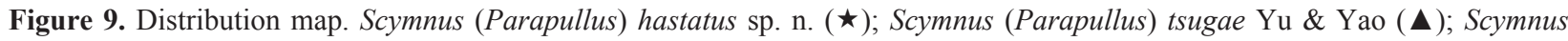
(Parapullus) alishanensis Pang \& Yu (•); Scymnus (Parapullus) baxianshanensis sp. n. (๘).

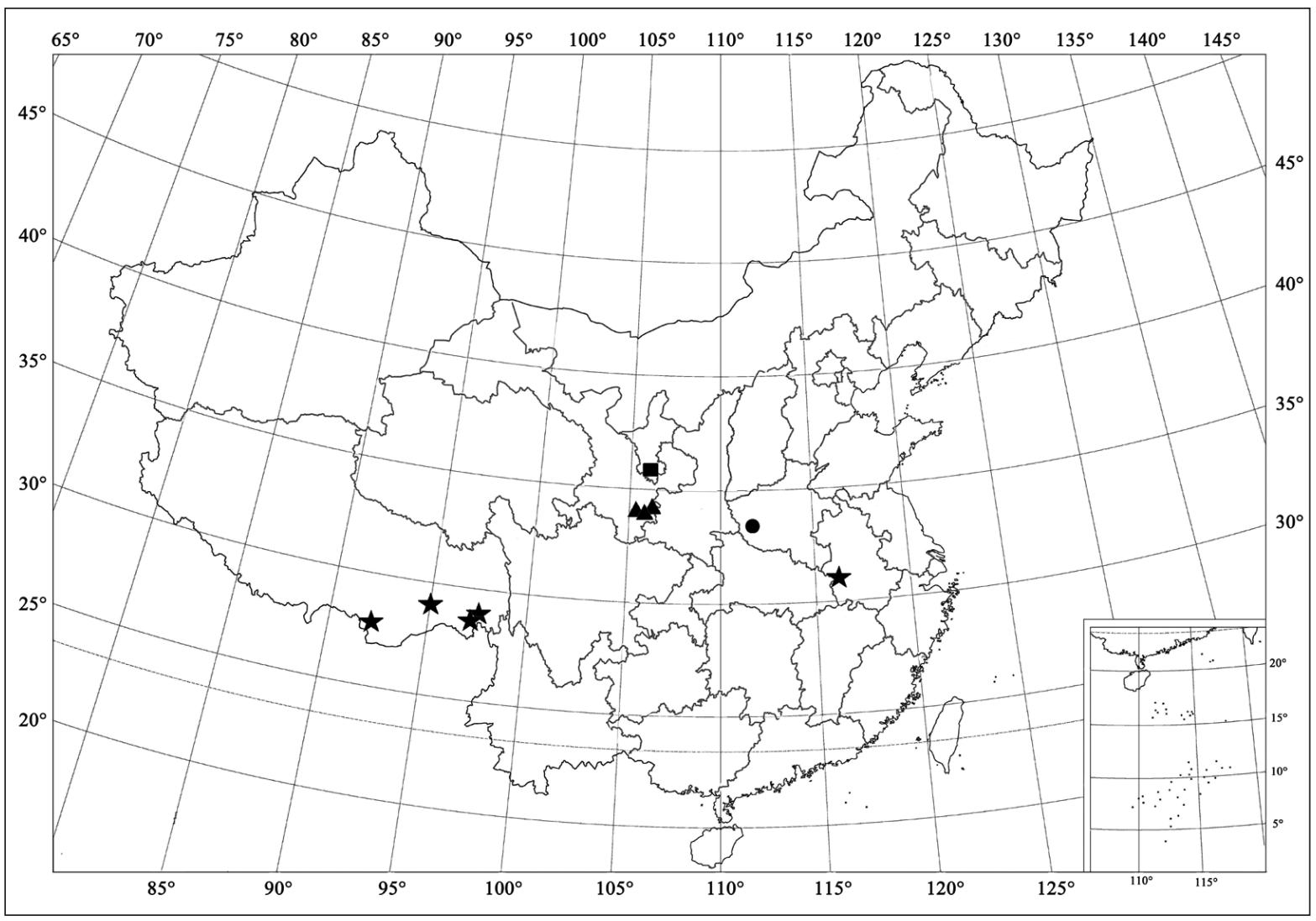

Figure 10. Distribution map. Scymnus (Parapullus) laojielingensis sp. n. (•); Scymnus (Parapullus) parallelicus Chen, Ren \&

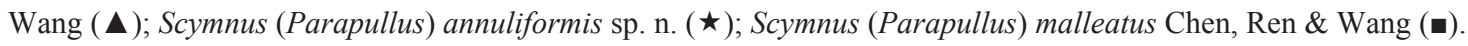




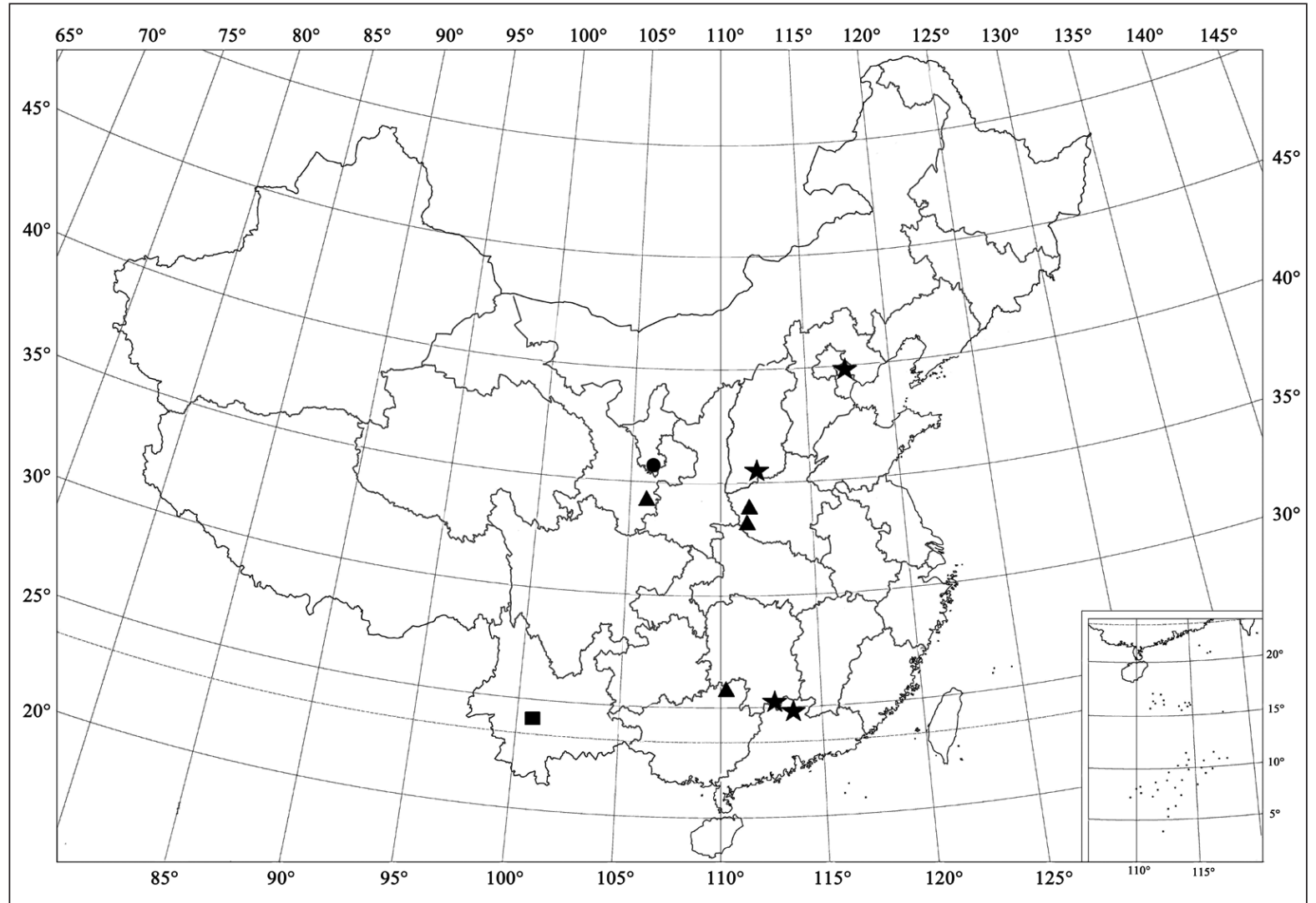

Figure 11. Distribution map. Scymnus (Parapullus) papillatus sp. n. ( $\star$ ); Scymnus (Parapullus) solus Chen, Ren \& Wang ( $\mathbf{\Delta}$ ); Scymnus (Parapullus) aduncatus Chen, Ren \& Wang (•); Scymnus (Parapullus) dichotomus sp. n.

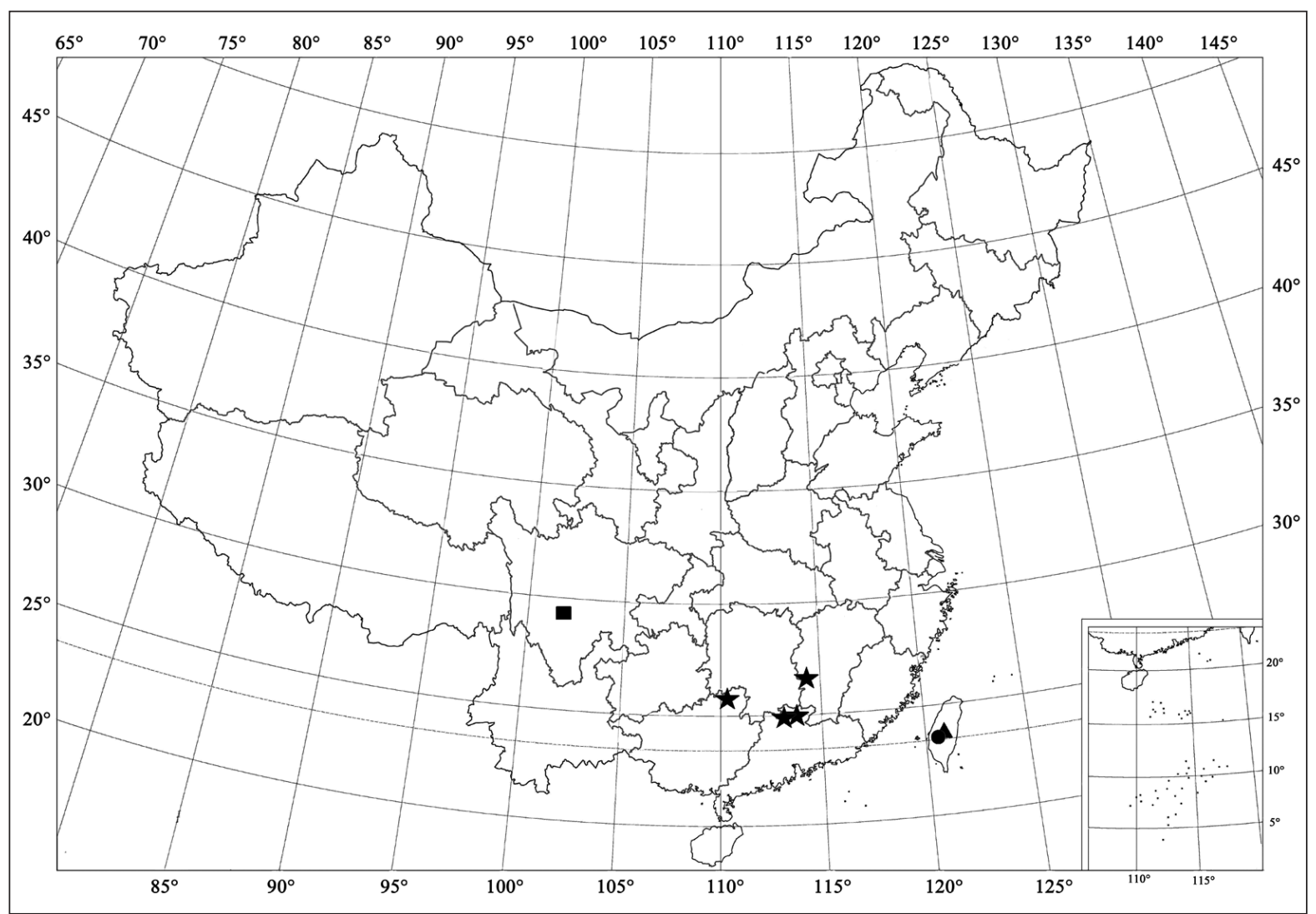

Figure 12. Distribution map. Scymnus (Parapullus) shenmuensis sp. n. (•); Scymnus (Parapullus) secula Yang (ム); Scymnus (Parapullus) nanlingicus Chen, Ren \& Wang ( $\star$ ); Scymnus (Parapullus) yanzigouensis sp. n. ( 
Type materials. Holotype: male, No. SCAU (E) 11531, China: Sichuan: Yanzigou, Gonggashan National Nature Reserve, Luding County, 2941.92'N, $102^{\circ} 0.22^{\prime} \mathrm{E}$, ca $2500 \mathrm{~m}, 28$. IX. 2007, Chen XS leg.

Paratypes (1): $1 \hat{\jmath}$ with same data as holotype.
Distribution. China (Sichuan).

Etymology. The specific epithet refers to its type locality, Yanzigou Scenic Spots, Gonggashan National Nature Reserve, Sichuan Province.

\section{Key to the Chinese species of the subgenus Scymnus (Parapullus) Yang}

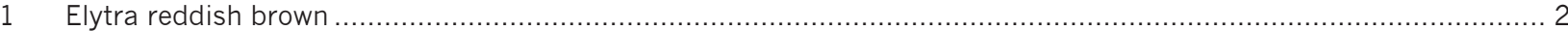

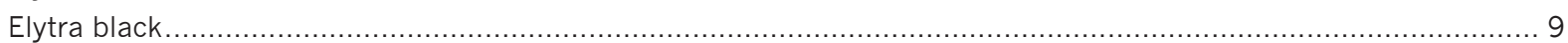

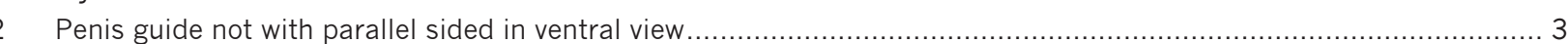

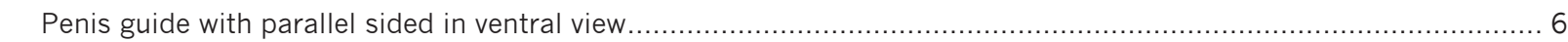

3 Parameres slender, slightly longer than penis guide (Fig. 1h); penis guide not constricted medially; apex of penis guide with hook-like appendage in lateral view (Fig. 1h) ........................................................ (P.) hastatus sp. n. Parameres stout, distinctly shorter than penis guide; penis guide constricted medially ...................................... 4

4 Penis capsule not emarginated medially; parameres broad, distinctly expanding toward apex.... S. (P.) tsugae Yu \& Yao

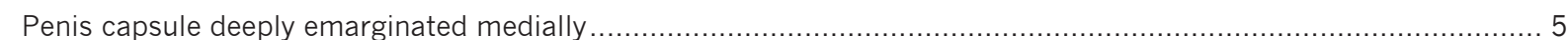

5 Parameres as long as $3 / 4$ length of penis guide ............................................................... (P.) alishanensis Pang \& Yu Parameres as long as $1 / 2$ length of penis guide (Fig. 2h).......................................... (P.) baxianshanensis $\mathrm{sp} . \mathrm{n}$.

6 Apex of penis stout with membranous appendage (Fig. 3f) ............................................ S. (P.) laojielingensis sp. n. Apex of penis slender without membranous appendage …....................................................................... 7

7 Prosternal process rectangular ....................................................................... (P.) parallelicus Chen, Ren \& Wang

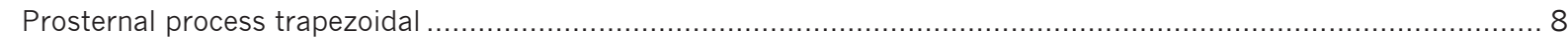

8 Abdominal postcoxal lines strongly recurved laterally (Fig. 4d); parameres narrow in lateral view (Fig. 4h) ..................

S. (P.) annuliformis sp. n.

Abdominal postcoxal lines weakly recurved laterally; parameres broad in lateral view... S. (P.) malleatus Chen, Ren \& Wang

9 Apex of parameres densely covered with one group of setae .................................................................. 10

Apex of parameres densely covered with two groups of setae ….............................................................. 11

10 On the inner side of paramere with a papilla bearing a stout seta at apical $1 / 3$ length (Fig. $5 \mathrm{~h}$ )...S. (P.) papillatus sp. $\mathrm{n}$.

- On the inner side of paramere smooth, not with a papilla appendage .............................. (P.) solus Chen, Ren \& Wang

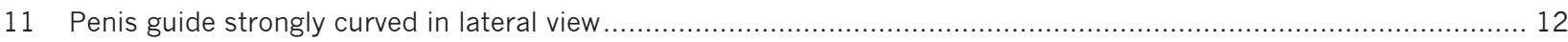

Penis guide straight or with apex slightly curved outwardly ...................................................................... 13

12 Prosternal process with lateral carinae parallel...................................................... S. (P.) aduncatus Chen, Ren \& Wang Prosternal process with lateral carinae convergent anteriorly ............................................. (P.) dichotomus sp. $\mathrm{n}$.

13 Pronotum brown with a large black marking (Fig. 7a) .......................................................... (P.) shenmuensis sp. n.

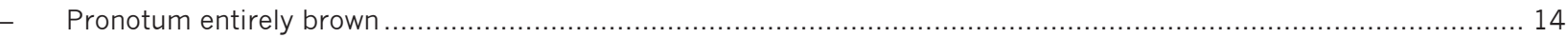

14 Penis capsule with outer arm narrow, sub-quadrate .............................................................. S. (P.) secula Yang

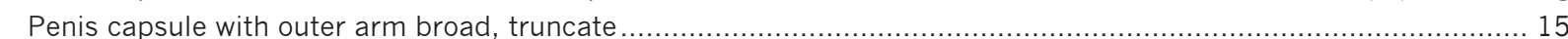

15 Area enclosed by abdominal postcoxal lines relatively narrow ................................ (P.) nanlingicus Chen, Ren \& Wang

- $\quad$ Area enclosed by abdominal postcoxal lines relatively broad (Fig. 8d) ................................ (P.) yanzigouensis sp. n.

Catalogue of the subgenus Scymnus (Parapullus) Yang, 1978

\section{Scymnus (Parapullus) abietis (Paykull, 1798)}

Coccinella abietis Paykull, 1798: 154.

Scymnus abietis: Mulsant 1850: 975; Weise 1879: 142;

Korschefsky 1931: 117; Gourreau 1974: 109.

Scymnus semilimbatus Fleischer, 1927: 260.

Scymnus (Scymnus) abietis: Bielawski 1968: 22; 1975 : 249; Soares et al. 2003: 27.

Scymnus (Parapullus) abietis: Pang and Yu 1993: 228; Kovář 2007: 584; Coutanceau 2009: 5; Chen et al. 2012: 22; Borowski 2015: 91.
Distribution. Austria, Belgium, Bulgaria, Belarus, Czech Republic, Denmark, Estonia, Finland, France, Germany, Hungary, Italy, Latvia, Norway, Poland, Romania, Russia, Slovakia, Sweden, Switzerland, Ukraine, Serbia and Montenegro, Mongolia.

\section{Scymnus (Parapullus) aduncatus Chen, Ren \& Wang, 2012}

Scymnus (Parapullus) aduncatus Chen, Ren \& Wang, 2012: 30.

Distribution. China (Ningxia). 
Scymnus (Parapullus) alishanensis Pang \& Yu, 1993

Scymnus (Parapullus) alishanensis Pang \& Yu, 1993: 230; Yu et al. 2000: 168; Pang et al. 2004: 82; Kováŕ 2007: 584; Ren et al. 2009: 68; Chen et al. 2012: 26.

Distribution. China (Taiwan).

Scymnus (Parapullus) annuliformis sp. $\mathrm{n}$.

Distribution. China (Anhui, Tibet).

Scymnus (Parapullus) baxianshanensis sp. $\mathbf{n}$.

Distribution. China (Tianjin).

Scymnus (Parapullus) coosi Hatch, 1961

Scymnus (Scymnus) coosi Hatch, 1961: 152. Gordon 1976: 20; 1985: 120.

Scymnus (Parapullus) coosi: Pang and Yu 1993: 229; Chen et al. 2012: 22.

Distribution. USA.

Scymnus (Parapullus) dichotomus sp. $\mathbf{n}$.

Distribution. China (Yunnan).

Scymnus (Parapullus) difficilis Casey, 1899

Scymnus (Scymnus) difficilis Casey, 1899: 154; Leng 1920: 214; Korschefsky 1931: 157; Gordon 1976: 19; 1985: 120.

Scymnus (Parapullus) difficilis: Pang and Yu 1993: 229; Chen et al. 22.

Distribution. USA.

Scymnus (Parapullus) hastatus sp. $\mathbf{n}$.

Distribution. China (Gansu).

Scymnus (Parapullus) laojielingensis sp. $\mathbf{n}$.

Distribution. China (Henan).

Scymnus (Parapullus) malleatus Chen, Ren \& Wang, 2012

Scymnus (Parapullus) malleatus Chen, Ren \& Wang, 2012: 24.

Distribution. China (Ningxia).

Scymnus (Parapullus) nanlingicus Chen, Ren \& Wang, 2012

Scymnus (Parapullus) nanlingicus Chen, Ren \& Wang, 2012: 32.

Distribution. China (Jiangxi, Guangdong, Guangxi).
Scymnus (Parapullus) nebulosus LeConte, 1852

Scymnus nebulosus LeConte, 1852: 137; Crotch 1874a: 262; Horn 1895: 95; Steinweden 1929: 29.

Scymnus (Scymnus) nebulosus: Casey 1899: 154; Leng 1920: 214; Korschefsky 1931: 163; Chapin 1974: 22; Gordon 1976: 13; 1985: 119.

Scymnus infuscatus Boheman, 1859: 208; Leng 1920: 214; Korschefsky 1931: 160; Gordon 1976: 15; 1985: 119. Synonymized by Gordon 1976: 15.

Scymnus phelpsii Crotch, 1874b: 77; Horn 1895: 96; Gordon 1976: 15; 1985: 120. Synonymized by Gordon 1976: 15 .

Scymnus (Scymnus) phelpsii: Casey 1899: 154; Leng 1920: 214; Korschefsky 1931: 165; Malkin 1943: 194; Hatch 1961: 153; Belicek 1976: 302; Gordon 1976: $15 ; 1985: 120$.

Scymnus (Scymnus) harneyi Hatch, 1961: 152; Gordon 1976: 15; 1985: 120. Synonymized by Gordon 1976: 15.

Scymnus (Parapullus) nebulosus: Pang and Yu 1993: 229; Chen et al. 2012: 22.

Distribution. Canada, USA.

Scymnus (Parapullus) papillatus sp. n.

Distribution. China (Shanxi, Tianjin, Hunan, Guangdong).

Scymnus (Parapullus) parallelicus Chen, Ren \& Wang, 2012

Scymnus (Parapullus) parallelicus Chen, Ren \& Wang, 2012: 24.

Distribution. China (Gansu).

Scymnus (Parapullus) secula Yang, 1978

Scymnus (Parapullus) secula Yang, 1978: 27; Pang and Yu 1993: 229; Yu et al. 2000: 167; Pang et al. 2004: 82; Kováŕ 2007: 584; Ren et al. 2009: 68; Chen et al. 2012: 32 .

Distribution. China (Taiwan).

Scymnus (Parapullus) shenmuensis sp. $\mathrm{n}$.

Distribution. China (Taiwan).

Scymnus (Parapullus) solus Chen, Ren \& Wang, 2012

Scymnus (Parapullus) solus Chen, Ren \& Wang, 2012: 29.

Distribution. China (Gansu, Henan, Guangxi).

Scymnus (Parapullus) tsugae Yu \& Yao, 2000

Scymnus (Parapullus) tsugae $\mathrm{Yu} \& \mathrm{Yao}$ in $\mathrm{Yu}$ et al. 2000: 168; Pang et al. 2004: 82; Kováŕ 2007: 584; Chen et al. 2012: 29.

Distribution. China (Yunnan). 
Scymnus (Parapullus) yanzigouensis sp. $\mathrm{n}$. Distribution. China (Sichuan).

\section{Acknowledgements}

We are deeply indebted to Mr. Rashid Azad (South China Agricultural University, China), who helped to check the English text. We are also grateful to the anonymous reviewers for their constructive and valuable comments and suggestions on our manuscript. The present study was supported by the Guangdong Natural Science Foundation (2014A030310493), the Science and Technology Program of Guangzhou, China (151800033) and the Science and Technology Partnership Program, Ministry of Science and Technology of China (KY201402014).

\section{References}

Belicek J (1976) Coccinellidae of western Canada and Alaska with analyses of the transmontane zoogeographic relationships between the fauna of British Columbia and Alberta (Insecta: Coleoptera: Coccinellidae). Quaestiones Entomologicae 12: 283-409.

Bielawski R (1968) Ergebnisse der zoologischen Forschungen von Dr. Z. Kaszab in der Mongolei Nr. 170. Coccinellidae IV (Coleoptera). Fragmenta Faunistica 15(3): 21-30. doi: 10.3161/00159301FF1968.15.3.021

Bielawski R (1975) Ergebnisse der zoologischen Forschungen von Dr. Z. Kaszab in der Mongolei Nr. 352. Coccinellidae V und VI (Coleoptera). Fragmenta Faunistica 20(16): 247-271.

Boheman CH (1859) Coleoptera. Species novas descripsit. In: Kongliga Svenska Fregatten Eugenies Resa Omkring Jorden unter Befall of C. A. Virgin, 1851-1853. Norstedt \& Söner, Stockholm. Zoologi. III. Insekter, 113-218.

Borowski J (2015) Beetles (Coleoptera) of the Rogów region. Part II: ladybirds (Coccinellidae). International Letters of Natural Sciences 34: 90-101. doi: 10.18052/www.scipress.com/ILNS.34.90

Casey TL (1899) A revision of the American Coccinellidae. Journal of the New York Entomological Society 7(2): 71-169.

Chapin JB (1974) The Coccinellidae of Louisiana (Insecta: Coleoptera). Louisiana Agricultural Experiment Station Bulletin 682: 2-87.

Chen XS, Ren SX, Wang XM (2012) Revision of the subgenus Scymnus (Parapullus) Yang from China (Coleoptera: Coccinellidae). Zootaxa 3174: 22-34.

Coutanceau JP (2009) Liste synonymique des Coléoptères Coccinellidae de France continentale et de Corse. Harmonia 3: 3-14.

Crotch GR (1874a) A revision of the Coleopterous family Coccinellidae. Cambriage University Press, London, 311 pp. doi: 10.5962/ bhl.title. 8975

Crotch GR (1874b) Descriptions of new species of Coleoptera from the Pacific Coast of the United States. Transactions of the American Entomological Society 5: 73-80.

Fleischer A (1927-1930) Přehled brouků fauny Československé republiky. Práce z entomologického oddělení Moravského zemského musea, Brno, č. 1.486 pp.

Gordon RD (1976) The Scymnini (Coleoptera: Coccinellidae) of the United States and Canada: Key to genera and revision of Scymmus, Nephus and Diomus. Bulletin of the Buffalo Society of Natural Sciences 28: 1-362.
Gordon RD (1985) The Coccinellidae (Coleoptera) of America North of Mexico. Journal of the New York Entomological Society 93(1): 1-912.

Gourreau JM (1974) Systematique de la tribu des Scymnini (Coccinellidae). Institut National de la Recherche Agronomique, Paris, $221 \mathrm{pp}$.

Hatch MH (1961) Beetles of the Pacific Northwest, Part III: Pselaphidae and Diversicornia. University Washington Press, Seattle, 503 pp.

Horn GH (1895) Studies in Coccinellidae. Transactions of the American Entomological Society 22: 81-114.

Korschefsky R (1931) Coleopterorum Catologus. Pars 118. Coccinellidae. I. Berlin, 224 pp.

Kováŕ I (2007) New nomenclatorial and taxonomic acts and comments. Coccinellidae. In: Löbl I, Smetana A (Eds) Catalogue of Palaearctic Coleoptera, Volume 4. Apollo Books, Stenstrup, 71-73, 568-631.

LeConte JL (1852) Remarks upon the Coccinellidae of the United States. Proceeding of the Academy of Natural Science of Philadelphia 6: $129-145$.

Leng CW (1920) Catalogue of the Coleoptera of America, north of Mexico. Mount Vernon, New York, 470 pp.

Malkin B (1943) A catalogue of Oregon Coccinellidae. Journal of the New York Entomological Society 51: 191-198.

Mulsant E (1850) Species de Coléoptères Trimères Sécuripalpes. Annales des Sciences Physiques et Naturelles, d'Agriculture et d'Industrie, publiées par la Société nationale d' Agriculture, etc., de Lyon, Deuxième Série 2: xv + 1-1104 pp (part 1 pp. 1-450; part 2 pp. 451-1104).

Pang XF, Yu GY (1993) Validity of Scymnus (Parapullus) Yang with description of a new species (Coleoptera: Coccinellidae) from Taiwan. The Coleopterists Bulletin 47(3): 228-231.

Pang H, Ren SX, Zeng T, Pang XF (2004) Biodiversity and their utilization of Coccinellidae in China. Science and Technology Press of Guangdong, Guangzhou, 168 pp. [In Chinese]

Paykull G (1798) Anmårkningar vid genus Coccinella, och beskisning öfver de Svånska arter deraf som åro med fina hår beströdde. Kongliga Vetenskaps Akademiens nya Handlingar 19: 144-156.

Ren SX, Wang XM, Pang H, Peng ZQ, Zeng T (2009) Colored pictorial handbook of ladybird beetles in China. Science Press, Beijing, 336 pp. [In Chinese]

Ślipiński A (2007)Australian ladybird beetles (Coleoptera: Coccinellidae): their biology and classification. ABRS, Canberra, 286 pp.

Ślipiński A, Tomaszewska W (2010) Coccinellidae Latreille, 1802. In: Leschen RAB, Beutel RG, Lawrence JF (Eds) Handbook of Zoology, Vol. 2, Coleoptera. Walter de Gruyter GmbH \& Co. KG, Berlin/New York, 454-472.

Soares AO, Elias RB, Raimundo A (2003) New records of Scymnini (Coleoptera: Coccinellidae) to Madeira Island. Boletim do Museu Municipal do Funchal 54(311): 25-29.

Steinweden JB (1929) Notes on the origin of the wax secretions of certain coccinellid larvae. Pan-Pacific Entomologist 6: 26-32.

Weise J (1879) Bestimmungs Tabellen der europaischen Coleopteren II. Coccinellidae. Zeitschrift für Entomologie (N. F.) (Breslau) 7: 88-156.

Yang CT (1978) A new subgenus and species of Coccinellidae. Bulletin of the Society of Entomology 13(1): 27-28.

Yu GY, Montgomery ME, Yao DF (2000) Lady beetles (Coleoptera: Coccinellidae) from Chinese hemlocks infected with the hemlock woolly adelgid, Adelges tsugae Annand (Homoptera: Adelgidae). The Coleopterists Bulletin 54(2): 154-199. doi: 10.1649/0010-065X( 2000)054[0154:LBCCFC]2.0.CO;2 